\title{
Közfoglalkoztatás a mezőgazdaságban
}

\section{Agricultural public works programmes in Hungary}

\author{
KOÓS BÁLINT
}

KoóS Bálint: tudományos munkatárs, MTA Közgazdaság- és Regionális Tudományi Kutatóközpont, Regionális Kutatások Intézete; 1112 Budapest, Budaörsi út 45.; koosb@rkk.hu

\section{KULCSSZAVAK: mezőgazdaság, közfoglalkoztatás}

ABSZTRAKT: A magyar foglalkoztatáspolitika évtized eleji átalakítása, a workfare jelleg erősítése alapjaiban formálta át a közfoglalkoztatási rendszert. A közmunkából, amely eredetileg csupán egy volt az aktív foglalkoztatáspolitikai eszközökből, s amely átmeneti vagy részmunkaidős elhelyezkedési lehetőséget kínált a tartós munkanélkülieknek, így vált egy univerzális, majd minden álláskereső számára elérhető, majdhogynem garantált elhelyezkedési lehetőséggé.

A közfoglalkoztatás új rendszerében kiemelt szerep jutott az ország legkedvezőtlenebb helyzetű térségeiben meghirdetett mezőgazdasági közfoglalkoztatási programoknak, amelyek a jó minőségű élelmiszerrel való ellátást biztosítják. A közfoglalkoztatás fizikai termékek előállításával való összekapcsolása nemzetközi szinten ritka, de nem példa nélküli. Argentínában és Indiában, ahol a közfoglalkoztatási programok keretén belül mezőgazdasági tevékenységek is megjelentek, hivatalosan nem kerülnek piaci forgalomba a megtermelt mezőgazdasági termékek, hiszen maguk a közmunkások, illetve a rászorulók étkeztetésére használják azokat.

A hazai gyakorlat e tekintetben legalábbis kétarcú, hiszen egyrészt határozott elvárás a piaczavarás elkerülése, ugyanakkor cél a fejlesztési projektek saját lábra állása, önfenntartóvá válása, ami végső soron a valódi piacra való kilépést jelenti. A politikai célok érthetőek, ugyanakkor nem jött létre egyetértés a tekintetben, hogy miként lehetne ezt elérni.

A magyar mezőgazdasági közfoglalkoztatási programok népszerűvé váltak, az érintettek számára ugyanis biztos, különösebb képzettséget nem igénylő munkalehetőséget teremtenek, még ha a piaci és a hivatalos minimálbérnél is alacsonyabb fizetést nyújtanak.

A 2012-2013. évekre vonatkozó teljes körü adatok alapján látható, hogy a hátrányos helyzetű térségekben meghirdetett mezőgazdasági közfoglalkoztatási programokba leginkább a hátrányos munkaerő-piaci helyzetűek - azaz nők, pályakezdő fiatalok, alacsonyan képzettek- kerülnek be. A mezőgazdasági közfoglalkoztatási programok foglalkoztatási reintegrációs hatása csekélynek mondható, az érintettek alig 9,9 százaléka tudott a munkaerőpiacon elhelyezkedni, legnagyobb valószínűséggel ismét közfoglalkoztatottakká váltak.

Bálint KOós: research fellow, Institute for Regional Studies, Centre for Economic and Regional Studies, Hungarian Academy of Sciences; Budaörsi út 45., H-1112 Budapest, Hungary; koosb@rkk.hu 
ABSTRACT: Hungarian employment policy changed fundamentally at the beginning of this decade. In regard to employment policy, a clear shift is observable from the welfare to the workfare approach.

This policy change reassessed the roles and functions of Hungarian public works programs. Previously, these were only one among many other active labor market policy measures, but recently, they have gained a more determining role. While traditionally, these programs provided only temporary (or part-time) employment for the long-term unemployed, after the welfare-system reform, they became a rather universal, almost granted employment opportunity for every unemployed. From among them, this study especially focuses on those special agricultural work programs, which, in the most disadvantaged areas, have been initiated in order to generate employment and provide quality food.

Internationally, direct agricultural production linked to public works programs is rare, but not unprecedented. Two cases are well-known in Argentina and India where agricultural products were utilized either by social institutions (e.g. soup kitchens) or by the public workers themselves.

Compared to these, the Hungarian practice represents a conflicting approach. On the one hand, the government seeks to avoid market disruption, while, on the other, it expects from these agricultural public work projects to become economically viable. While the political objectives are clear, there is no common understanding on how to achieve them. The agricultural public works programs have become widely used in the most disadvantaged areas as they provide stable and low-skilled jobs for the unemployed, even if they offer wages far below the market average and the national minimum rate.

Based on comprehensive data about the programs' first two years (2012 and 2013), it is visible that participants for the agricultural public works programs were recruited from the most disadvantaged, 'hard to employ' groups (mostly low skilled or un-skilled women, elders, and youth).

These agricultural public works programs had very limited impact on participants' employment opportunities as only $9.9 \%$ of them had been able to find a job on the primary job market. The majority of the participants has likely became re-employed in other public works programs.

\section{Bevezetés}

2011-ben Magyarországon kísérleti program indult az aktív foglalkoztatáspolitikai eszköztárba tartozó közfoglalkoztatás mezőgazdasági tevékenységekre való kiterjesztésére. A Heves megyében beindított mintaprogram részeként a közfoglalkoztatottak önkormányzati földeken végeztek növénytermesztési munkákat, valamint erdőtelepítést. A programot beindító Belügyminisztérium sikeresnek ítélte a mintaprogramot és területi hatályát kiterjesztette, széles kör számára téve elérhetővé a mezőgazdasági jellegü közfoglalkoztatási programokban való részvételt. Alig négy év alatt az agrár-közfoglalkoztatási programok olyan népszerüvé váltak, hogy 2015-ben havi átlagban már 37 ezer fó közfoglalkoztatott ${ }^{1}$ végzett mezőgazdasági termelő jellegü munkát. Ennek nagyságrendjét jól érzékelteti, hogy Magyarországon az Eurostat adatai alapján 2014-ben 124800 fó dolgozott fizetett munkásként ${ }^{2}$ az ágazatban. Míg a közfoglalkoztatás egészét komoly szakmai érdeklődés kíséri (többek mellett ÁSZ 2013; Czirfusz 2015; Csoba 2010; Hamar 2010; Koltai 2014; Váradi 2010, 2015), a mezőgazdasági közfoglalkoztatás mindeddig háttérbe szorult, pedig a hazai közfoglalkoztatási programok e szelete nemzetközi szinten is sajátosnak, bár nem példa 
nélkülinek mondható. Jelen írás célja a magyar mezőgazdasági közfoglalkoztatási program vázlatos bemutatása, nemzetközi kontextusba helyezése, s a közmunkát végzők főbb demográfiai és szociális jellemzőinek bemutatása.

\section{A közfoglalkoztatás mint eszköz}

A közfoglalkoztatás mint közpolitikai eszköz, igazodva a társadalmi, politikai, gazdasági körülményekhez, eltérő célokat szolgálhat. Az állami forrásokból megvalósított munkahelyteremtés napjainkban leginkább hármas célt szolgál (Lieuw-Kie-Song, Philip, Tsukamoto, Van Imschoot 2010): a szegénység mérséklését, a foglalkoztathatóság javítását, valamint a közjavak - infrastruktúra, közszolgáltatások - eloállítását, nyújtását. E célok nem különülnek el egymástól élesen, a foglalkoztathatóság javítása nyilvánvalóan a szegénység elleni küzdelmet is segíti. A közfoglalkoztatási programok meghirdetését egyéb közpolitikai célok is motiválhatják - mint például természeti katasztrófák, háborús károk helyreállítása, de a gazdasági vagy munkaerő-piaci válság kezelése, sőt akár a hiányos szociális háló pótlása is meghúzódhat a háttérben.

Magyarország esetében a mezőgazdasági közfoglalkoztatási rendszer létrejötte az aktív foglalkoztatáspolitikához, azaz a fenti meghatározás alapján a foglalkoztathatóság javításához kapcsolódik. Ezt a foglalkoztatáspolitikai célt azonban egyre inkább felülrétegezik más társadalompolitikai célok, amelyek néha bizony mintha háttérbe is szorítanák az eredeti célkitűzést.

A magyar szociálpolitika évtized eleji irányváltása teremtette meg a feltételeit a közfoglalkoztatás mezőgazdaságra történő kiterjesztésének. A „segély helyett munka" politikai célkitűzésének gyakorlatba ültetése az egységes közfoglalkoztatási rendszer 2011-es létrehozása, illetve a szociális ellátások átalakítása révén valósult meg, egyértelműen a workfare rendszer irányába tolva el a hazai gyakorlatot (Kálmán 2015). Ez a szemléletváltás korántsem egyedülálló, hiszen az Amerikai Egyesült Államokban 1981-től sorra indultak olyan programok, amelyek a jóléti ellátást közcélú munkához kapcsolták (Nathan 2000), ami határozott elmozdulást jelentett a korábban meghatározó welfare megközelítéstől a workfare rendszer irányába. Ez a reagani reform a közcélú munkavégzést újrapozicionálta, hiszen korábban ez egyértelműen egy makrogazdasági sokk által létrejött válsághelyzet kezelését célzó anticiklikus eszközt jelentett. A gazdasági válság időszakában a piac nem képes elegendő keresletet támasztani a munkaerő iránt, aminek eredményeként tömeges és tartós munkanélküliség alakul ki, ez tovább mérsékli a keresletet, újabb leépítéseket generálva. A keynesi beavatkozási logika szerint amennyiben a piac elégtelen keresletet támaszt a munkaerő iránt, akkor az államnak kell új, fizetett munkahelyeket teremtenie (Keynes 1965), hogy a pótlólagos kereslettel elősegítse a gazdasági fellendülést, hiszen a többletkereslet révén bővülhet a foglalkoztatás és ezzel megszakítható az 
önmagát erősítő negatív gazdasági folyamat, amely a válság elmélyüléséhez vezetett. Az 1929-es gazdasági világválság nyomán világszerte indultak olyan kormányzati, önkormányzati programok, amelyek munkanélküliek számára nyújtottak munkalehetőséget - a legismertebb Roosevelt elnök New Deal programja, amely jelentős infrastruktúra-fejlesztések - utak, hidak, víztározók - építése révén teremtett új munkahelyeket. A válságos években Magyarországon is elindultak efféle közmunkaprogramok, de jóval kisebb léptéküek voltak. A gazdasági válság sújtotta országban képzettség szerint differenciált közmunkaprogramok indultak: a szakképzettek számára „szükségmunkát”, a képzetlenek számára pedig „ínségmunkát” (Gyáni 2011) szerveztek a nagyobb lélekszámú települések önkormányzatai. A szakképzetlen munkaerő az ínségmunka keretein belül jellemzően infrastruktúra-építési (utak, csatornák kialakítása), parkosítási, tereprendezési, erdősítési feladatokat végzett (Magyarosi 2015). Az értelmiségiek számára jóval nehezebb volt munkalehetőséget biztosítani, ők jellemzően a különböző közszolgáltatások - különösen a szegényügyi ellátás - területén helyezkedhettek el.

Az államszocializmus időszakában, a teljes foglalkoztatás idején ilyen típusú közpolitikákra - tekintsük azokat akár foglalkoztatáspolitikai, akár szociális célúaknak - nem volt szükség. A rendszerváltással a helyzet gyökeresen megváltozott, 1991-ben a közhasznú foglalkoztatást, 1996-ban a közmunkaprogramokat, 2000-ben pedig a közcélú foglalkoztatást vezették be (Csoba 2010). E programok közös vonása, hogy az ellátás feltételéül, a jogosultság megszerzéséhez bizonyos, társadalmi szempontból hasznos munkavégzést kötöttek ki. E programok jellemzően rövid idejűek voltak - a közcélú foglalkoztatás 30 napot jelentett - és viszonylag szűk kört érintettek (ÁSZ 2007). Változást 2008-ban az Út a munkához program hozott, amely jelentős forráskeretet kapott a közcélú foglalkoztatás kiterjesztésére, s új elemként megjelent benne a foglalkoztathatóság javítását célzó képzési komponens is: a 35 év alatti, általános iskolát be nem fejezettek számára a képzésen való részvétel kötelezővé vált. Mindhárom hazai közfoglalkoztatási forma esetén a programba bevontak minimálbért kaptak, s így váltak jogosulttá a jóléti ellátásra (munkanélküli segély, az Út a munkához idején foglalkoztatást helyettesítő támogatás). A programban részt vevők jellemzően települési közfeladatok ellátásával kapcsolatos munkákat végeztek, így például közterületek, utak tisztítása, zöldfelületek gondozása, árkok karbantartása volt a feladatuk. E programok rendkívül fontos munkaerő-piaci, szociális feladatot töltöttek be azzal, hogy kötődést, kapcsolatot hoztak létre az elsődleges munkaerőpiacról tartósan kiszorultak s a munka világa közt, hozzájárultak az érintettek munkaképességének valamilyen szintủ megőrzéséhez, s többletjövedelmet biztosítottak a nehéz anyagi körülmények közt élők számára. A program értékelését végzők ugyanakkor rámutattak arra, hogy a program foglalkoztatási hatása minimális, az érintett tartós munkanélküliek az elsődleges munkaerőpiacon továbbra sem képesek elhelyezkedni (Scharle 2011; Váradi 2010).

A közfoglalkoztatás csupán egy, s nem is a legfontosabb eszköz volt az aktív foglalkoztatáspolitika eszközei közül, amely alapvetően egy időszakosnak tekintett 
gazdasági válság negatív munkaerő-piaci következményeinek enyhítését célozta. Ebben az időszakban a hazai közfoglalkoztatás cél- és eszközrendszere illeszkedett a fejlett világ országaiban alkalmazott aktív foglalkoztatáspolitika gyakorlatához, hiszen számos országban indultak ilyen közfoglalkoztatási programok globális, illetve regionális válságok nyomán (Subbarao, Ninno, Andrews, Rodríguez-Alas 2013). E külföldi programok alapvetően a munkaerőpiacról kiszorultak átmeneti foglalkoztatását szolgálták, hogy a gazdaság strukturális igazodását követően ismételten lehetővé váljon elhelyezkedésük az elsődleges munkaerőpiacon. A közfoglalkoztatás ennek megfelelően kettős célt követett: a foglalkoztathatóság megőrzését (javítását) és az elszegényedés megelőzését célozta.

A közfoglalkoztatás azonban nem csupán a fejlett országokban alkalmazott foglalkoztatáspolitikai eszköz, a fejlödő országokban éppen úgy alkalmazzák, az eltérő feltételek miatt azonban némileg más cél- és eszközrendszerrel. A legfontosabb eltérésnek az tekinthető, hogy a közfoglalkoztatási programok nem idöszakos gazdasági sokk, hanem strukturális, tartós problémák kezelését célozzák. Ilyen tartós problémának tekinthetők a közlekedés, a víz- és energiaellátás infrastrukturális elemeinek hiánya, a mezőgazdaság szűk és időben ingadozó foglalkoztatási kapacitása, amelyet egyes országokban súlyos élelmiszer-ellátási problémák tetéznek. A klasszikus példának számító Marokkóban 1961-ben indult az a mai napig működő program (Promotion Nationale), amely összekapcsolta a szezonális mezőgazdasági munkanélküliség kezelését és az infrastruktúra fejlesztését. A marokkói program célrendszere idővel kibővült, közvetlen területfejlesztési és szociális célok elérése érdekében is alkalmazzák, ennek köszönhetően az elmaradott vidéki területek intézményellátottsága (oktatási, egészségügyi intézmények építése révén), megközelíthetősége javult és jelentősen fejlődött az ivóvízellátás minősége is (Jalal 2007). Hasonló kezdeményezésnek tekinthetők a bangladesi, etióp, indiai, dél-afrikai, argentin közfoglalkoztatási programok. E programok főbb jellemzőiről nyújt áttekintést az 1. táblázat.

A fejlődő és fejlett országok közfoglalkoztatási programjai közös vonásokat is mutatnak: alapvetően rövid távú foglalkoztatási lehetőséget biztosítanak a munkanélküliek számára s jövedelemtranszfer révén mérséklik a szegénységet, ugyanakkor eltérést jelent, hogy a fejlődő országok esetében a területfejlesztési cél, míg a fejlett országok esetében a foglalkoztathatóság javítása bír nagyobb jelentőséggel. Ez tükröződik abban is, hogy a fejlődő országokban inkább projektalapú, míg a fejlett országokban elsősorban programalapú megközelítés a jellemző. A fejlődő országok esetében a projektek kiválasztása során egyaránt található top-down (Marokkó), illetve bottom-up (India) megközelítés. Marokkóban, ahol az alapvető vonalas infrastruktúra kiépítése volt a fókuszban, a központi szervezés a meghatározó, míg Indiában a választott helyi képviselőkből álló tanács dönt a megvalósítandó fejlesztésekről. (A helyi választott képviselők bevonása a döntésbe fontos közösségépítő elem.) Több program esetében ehhez hozzáadódik különböző szociális szolgáltatások fejlesztése - pl. AIDS-betegek ellátása Dél-Afrikában, idősgondozás Argentínában -, ami fóként nők számára te- 
1. táblázat: Fejlődő országok közfoglalkoztatási programjainak főbb jellemzői The main characteristics of public works programs in developing countries

\begin{tabular}{|c|c|c|c|}
\hline Ország (program) & Tevékenységek & Idöszak & Célcsoport/terület \\
\hline $\begin{array}{l}\text { Marokkó } \\
\text { (Promotion Nationale, } \\
1961-\text { ) }\end{array}$ & $\begin{array}{l}\text { - Vidéki területeken: vízellátás biz- } \\
\text { tosítása (kutak, csatornák építése); } \\
\text { közlekedés fejlesztése (utak építése); } \\
\text { erdősítés } \\
\text { - Városi területeken: közintézmé- } \\
\text { nyek építése (egészségügy, oktatás) } \\
\text { szociális ellátás }\end{array}$ & $\begin{array}{l}\text { Szezonális - } \\
\text { aszályos, száraz } \\
\text { időszakban } \\
\text { Átlagosan } 43 \\
\text { nap }\end{array}$ & $\begin{array}{l}\text { Képzetlenek, } \\
\text { alulfoglalkozta- } \\
\text { tottak, illetve } \\
\text { munkanélküliek } \\
\text { Döntően férfiak } \\
\text { (80\%) } \\
\text { Területileg cél- } \\
\text { zott } \\
\text { Évente kb. } \\
50000 \text { fö } \\
\text { Bérköltség: } 75 \%\end{array}$ \\
\hline $\begin{array}{l}\text { Banglades } \\
\text { (Labour Intensive Public } \\
\text { Works Project, 1975-) }\end{array}$ & $\begin{array}{l}\text { - Közlekedési utak építése, felújítása } \\
\text { - Öntözőcsatornák építése, karban- } \\
\text { tartása } \\
\text { - Árvízvédelmi gátak építése }\end{array}$ & $\begin{array}{l}\text { Szezonális - } \\
\text { száraz évszak, } \\
\text { illetve árvízi } \\
\text { védekezés ese- } \\
\text { tén } \\
\text { Legfeljebb } 100 \\
\text { napos részvétel } \\
\text { biztosított }\end{array}$ & $\begin{array}{l}\text { Döntően férfiak } \\
\text { Bérköltség: 60- } \\
70 \%\end{array}$ \\
\hline $\begin{array}{l}\text { India } \\
\text { (Mahatma Gandhi Nati- } \\
\text { onal Rural Employment } \\
\text { Guarantee Scheme, } \\
\text { 2006-) }\end{array}$ & $\begin{array}{l}\text { - } \quad \text { Árvízvédelem, vízellátás, öntöző- } \\
\text { csatornák építése, karbantartása (52\%) } \\
\text { - } \quad \text { Közlekedési utak építése, felújítása } \\
\text { és intézmények fejlesztése (19\%) } \\
\text { - } \quad \text { Mezőgazdasági munkák (14\%) } \\
\text { - } \quad \text { Erdősítés, talajvédelem (13\%) }\end{array}$ & $\begin{array}{l}\text { Folyamatos } \\
\text { (100 nap rész- } \\
\text { vétel mindenki } \\
\text { számára garan- } \\
\text { tált) } \\
\text { Átlagosan } 53 \\
\text { nap }\end{array}$ & $\begin{array}{l}\text { Közel kiegyensú- } \\
\text { lyozott (férfi 52- } \\
58 \% \text { ) } \\
\text { Területileg cél- } \\
\text { zott: csak vidéki } \\
\text { területeken } \\
\text { Évente } 50 \text { millió } \\
\text { háztartás } \\
\text { Bérköltség: } 60 \% \\
\end{array}$ \\
\hline $\begin{array}{l}\text { Dél-Afrika } \\
\text { (Expanded Public Works } \\
\text { Program, 2004-) }\end{array}$ & $\begin{array}{l}\text { - Infrastruktúra fejlesztése (utak, } \\
\text { járdák, közmüárkok építése, vízkárok } \\
\text { mérséklése) } \\
\text { - } \quad \text { Tájrehabilitáció } \\
\text { - } \quad \text { Szociális ellátás (AIDS-betegek } \\
\text { ápolása, gyermekgondozás) }\end{array}$ & $\begin{array}{l}\text { 4-12 hónap idő- } \\
\text { tartam }\end{array}$ & $\begin{array}{l}\text { Főként férfiak } \\
(60 \%) \\
\text { Országos } \\
\text { Évente kb. } \\
50000 \text { fö } \\
\text { Bérköltség: n.a. }\end{array}$ \\
\hline $\begin{array}{l}\text { Argentína } \\
\text { (Jefes de Hogar, 2002- } \\
\text { 2009) }\end{array}$ & $\begin{array}{l}\text { - Közintézmények (oktatási, egész- } \\
\text { ségügyi, szociális) } \\
\text { - Szociális ellátás (idősek és gyer- } \\
\text { mekek gondozása, iskolai étkeztetés és } \\
\text { közkonyhák müködtetése) } \\
\text { - Mezőgazdasági tevékenység, kö- } \\
\text { zösségi kertek } \\
\text { - } \quad \text { Képzések }\end{array}$ & Folyamatos & $\begin{array}{l}\text { Főként nők } \\
\text { (70\%), nagy ré- } \\
\text { szük korábban } \\
\text { inaktív volt } \\
\text { Bérköltség: } 40 \%\end{array}$ \\
\hline
\end{tabular}




\begin{tabular}{|c|c|c|c|}
\hline Ország (program) & Tevékenységek & Idöszak & Célcsoport/terület \\
\hline $\begin{array}{l}\text { Argentína } \\
\text { (Trabajar, 1997-2001) }\end{array}$ & $\begin{array}{l}\text { - Infrastruktúra (utak, csatornák, } \\
\text { árkok építése, felújítása } \\
\text { - Oktatási és közösségi épületek épí- } \\
\text { tése, felújítása } \\
\text { - } \quad \text { Közösségi kertek (a projektek 5\%-a) }\end{array}$ & $\begin{array}{l}\text { Folyamatos } \\
\text { Átlagosan 4,5 } \\
\text { hónap }\end{array}$ & $\begin{array}{l}\text { Főként munka- } \\
\text { nélküli férfiak } \\
\text { Bérköltség: } 60 \%\end{array}$ \\
\hline $\begin{array}{l}\text { Etiópia } \\
\text { (Productive Safety Net } \\
\text { Program, 2005-) }\end{array}$ & $\begin{array}{l}\text { - Infrastruktúra (vízellátás (víztáro- } \\
\text { zók, kutak), utak építése, felújítása, } \\
\text { vízkárok mérséklése (záportározók, ár- } \\
\text { kok) } \\
\text { - Oktatási intézmények építése } \\
\text { - Mezőgazdasági öntözési rendszer } \\
\text { kialakítása (csak a rászoruló nők által } \\
\text { vezetett gazdaságok esetében) }\end{array}$ & $\begin{array}{l}\text { Folyamatos } \\
\text { 4-6 hónap idő- } \\
\text { tartam }\end{array}$ & $\begin{array}{l}\text { Területileg cél- } \\
\text { zott } \\
\text { Főként férfiak } \\
(90 \%) \\
\text { Évente kb. } 7,6 \\
\text { millió fö } \\
\text { Bérköltség: n.a. }\end{array}$ \\
\hline
\end{tabular}

Forrás: saját szerkesztés Subbarao, Ninno, Andrews, Rodríguez-Alas 2013; UNDP 2015; World Bank 2007 alapján.

remt munkalehetőséget. A képzési komponens ugyanakkor nem, vagy csupán csekély mértékben jelenik meg ezekben a közfoglalkoztatási programokban, s jellemzően nem is formális képzést jelent, hanem például az alapvető higiéniás szabályok, viselkedési minták vagy éppen a munkakultúra átadását célozzák.

A fejlesztési komponens miatt a fejlődő országok közmunkaprogramjai nem csupán bérjellegű kifizetésekre nyújtanak fedezetet, hanem változó arányban az anyagköltségre is. Ennek megfelelően a programok költségeinek 40-75 százalékát a bérek teszik ki, legmagasabb béraránnyal a szociális jellegü projekteknél találkozhatunk. A bérarány emelése, azaz a minél több munkahely teremtése érdekében Indiában kifejezetten tiltják gépek (pl. földmunkagépek) alkalmazását, ami még indiai viszonyok mellett is anakronisztikus, nehezen betartható elvárás. A résztvevők motivációját nem csupán ez rombolja, hanem az is, hogy a költségek leszorítása érdekében sok esetben korlátozzák az anyagbeszerzést, ami azt eredményezi, hogy a fejlesztések gyakran nem fenntarthatóak - az első komolyabb eső, monszunidőszak megrongálja az elkészült földteraszokat, csatornákat, hidakat, így végső soron a fejlesztések csak látszólagosak, érdemben nem javítják az ott élők helyzetét.

A közmunkaprogramok a fejlődő országokban jellemzően az infrastruktúra fejlesztéséhez, kisebb mértékben szociális jellegű ellátáshoz kapcsolódnak, de három ország esetében feltűnnek köztük közvetlen mezőgazdasági jellegű projektek is. Etiópiában egy jól körülhatárolt társadalmi csoport - a rászoruló nők által vezetett kisgazdaságok - esetében közmunkaprogram keretében lehetséges a gazdaságok öntözési rendszerének kiépítése, hogy ezzel is javuljon a célcsoport jövedelmi helyzete. Argentínában mind a Jefes, mind pedig a Trabajar program keretében támogattak kis léptékű mezőgazdasági vállalkozásfejlesztési projekteket (pl. öntözés fejlesztése), de a közösségi kertek révén közvetlen mezőgazdasági termelésre is volt példa. Argentínában összekapcsolódott a közös- 
ségi kertek és a közkonyhák müködtetése, a megtermelt alapanyagokból a közkonyhák révén javították a rászorulók élelmezési helyzetét, egyes esetekben az iskolai étkeztetéshez is hozzájárultak. A beavatkozás ugyanakkor nagyon limitált volt, a Világbank hiteléből finanszírozott argentin program keretében alig 65 közösségi kertet valósítottak meg, amelyekben 1300 fő végzett közmunkát.

A mezőgazdasági közfoglalkoztatás jóval nagyobb jelentőségű a 2006-ban indult indiai programban, amely méreténél, kiterjedtségénél fogva inkább szociálpolitikai, semmint foglalkoztatáspolitikai indíttatásúnak tekinthető. Az arányokat jól érzékelteti, hogy míg az argentin Jefes programban közel 122 ezer fó kapott munkalehetőséget, az indiai Mahatma Gandhi nemzeti vidéki foglakoztatási garanciatörvény évente durván 50 millió vidéki háztartást ér el. Az indiai program mezőgazdasági jellegű munkái döntően közösségi tulajdonú földeket érintettek, ahol talajminőség javítására, erdősítésre, illetve öntözési rendszerek kialakítására került sor. Magántulajdonú földeken csak abban az esetben valósulhatnak meg közfoglalkoztatási projektek, ha ezek révén javíthatóak a leghátrányosabb helyzetű, kaszton kívüli „érinthetetlenek”, illetve a két hektárnál kisebb földet művelők helyzete. A magántulajdonban lévő földeken végzett közmunka meglepően nagy jelentőségű - az összes projekt 14 százaléka tekinthető ilyennek -, e körben leggyakrabban az öntözés feltételeinek megteremtésére (vízgyüjtők és kutak kialakítása) került sor. E körben végzett vizsgálatok arra a következtetésre jutottak, hogy a beavatkozás révén az érintettek 85 százalékának javult a helyzete, 42 százaléka pedig többet nem vett részt a programban, mert már nem volt rászorult, s az érintettek 49 százaléka jelezte, hogy a fejlesztés révén javult hitelképessége, ami új forrásokat nyithat meg a gazdaság fejlesztéséhez (UNDP 2015).

Indiában azonban nem csupán beruházási jellegüek az agrár-közfoglalkoztatási projektek: akárcsak Argentína esetében, itt is megjelenik a direkt mezőgazdasági termelés, csak jóval nagyobb volumenben. A Mahatma Gandhi nemzeti vidéki foglakoztatási garanciatörvény megvalósításához kapcsolódik a leghátrányosabb helyzetű, kaszton kívüli „érinthetetlenek” helyzetének javítását célzó beavatkozás, amely használaton kívüli közösségi földek mezőgazdasági hasznosítását célozza. A szabad földterületeken (pl. utak és csatornák mentén) a kedvezményezettek bevonásával ültetvényeket alakítanak ki, amelyek gondozása, öntözése tartós feladatot jelent a közfoglalkoztatottak számára, segítve őket anyagi és élelmezési helyzetük javításában. India egészére nem állnak rendelkezésre kimutatások, de a helyzetet jól érzékelteti, hogy a 35 milliós lakosú Telangana szövetségi államban 2015-ig

- közel 79 ezer hektárnyi területen folyt támogatott kertészeti tevékenység 89 ezer kedvezményezettet bevonva;

- 400 ezer közfoglalkoztatottat bevonva 85 millió facsemetét (leginkább mangót és kókuszt) ültettek kihasználatlan közterületeken (utak és csatornák mentén); 
- a 2014-ben indult Indiramma Pachha Thoranam program keretén belül pedig 1,25 millió palántát ültettek 7000 kaszton kívüli kedvezményezett megélhetésének javítására (Telangana 2015).

\section{A hazai közfoglalkoztatási rendszer}

Magyarországon 2011-től alapvetően átalakult a közfoglalkoztatás rendszere, megszűnt a korábbi közmunkaprogram, a közcélú munka és a közhasznú munkavégzés, ezek helyébe az egységes közfoglalkoztatási rendszer lépett. A közfoglalkoztatási rendszer kialakításakor a deklarált cél ${ }^{3}$ az volt, hogy társadalmilag hasznos, értéket teremto foglalkoztatási formák révén („segély helyett munka") biztosítsák a munkaerőpiacról kiszorultak széles köreinek aktivizálását, munkaképességük megőrzését, s hogy munkarutin megszerzésével segítsék elhelyezkedésüket az elsődleges munkaerőpiacon.

A közfoglalkoztatás 2011-es indulását követően mind a ráfordított közpénz összege, mind az érintett személyek száma korábban nem látott jelentőségre tett szert (2. táblázat). 2014-ben 231 milliárd forint ráfordítás révén a magyar lakosság huszada $(5,6 \%)$ vett részt valamilyen közfoglalkoztatási programban, ami nemzetközi összehasonlításban is rendkívül magasnak ítélhető (Kálmán 2015).

A hazai közfoglalkoztatási rendszer másik jellemzője, hogy a programban részt vevők nem munka-, hanem egy sajátos közfoglalkoztatási jogviszonyba kerülnek, amely sok tekintetben közel áll a határozott idejű munkaszerződésen alapuló foglalkoztatáshoz: így például jogosultságot biztosít a társadalombiztosítási ellátásokra, fizetett szabadságra (egységesen évi 20 nap), de a közfoglalkoztatottak bére nem éri el a garantált bérminimumot. A közfoglalkoztatás így félúton jár a munkanélküliség és az elsődleges munkaerőpiacon való foglalkoztatás közt: több dimenzióban is a foglalkoztatást imitálja, de annál kedvezőtlenebb kondíciókat kínál, annak érdekében, hogy a közfoglalkoztatottakat piaci munkavállalásra ösztönözze.

2. táblázat: A Nemzeti Foglalkoztatási Alap startmunkaprogram kiadási előirányzatának mértéke és a közfoglalkoztatási programokban részt vevők létszámadatai

The assigned costs and employee numbers in Hungarian public works programs (2011-2015)

\begin{tabular}{ccc}
\hline Év & Elöirányzat (milliárd Ft) & A közfoglalkoztatási programokban részt vevök létszámadatai (fö) \\
\hline 2011 & 64,0 & 35033 \\
2012 & 137,5 & 271625 \\
2013 & 180,0 & 402693 \\
2014 & 231,0 & 561214 \\
2015 & 270,0 & n.a. \\
\hline
\end{tabular}

Forrás: Lőrincz 2015. 


\section{Kistérségi, illetve járási startmunka-mintaprogramok}

A közfoglalkoztatási programok mezőgazdasági tevékenységekre történő kiterjesztése a 2011-ben induló kistérségi startmunka-mintaprogramokhoz kötődnek. E mintaprogramok több szempontból is újszerűnek bizonyultak. Egyrészről területileg célzottak voltak: területfejlesztési, illetőleg településfejlesztési dimenzióval ruházták fel ezt a foglalkoztatáspolitikai eszközt, hiszen csupán a hátrányos helyzetü kistérségekben, ${ }^{4}$ illetve a hátrányos helyzetű településeken ${ }^{5}$ vehetik igénybe a forrásokat. A jogosult települések, térségek az ország klasszikus fejletlen, válság sújtotta területeit ölelik fel (Pénzes 2014), ahol tartósan magas munkanélküliség és a szociális problémák halmozódása jellemző (1. ábra). Ez az erőteljes területi célzás egyben azt is jelenti, hogy a mintaprogramok alapvetően strukturális, s nem pedig gazdasági ciklushoz kötődő probléma kezelését célozzák. Ezzel függ össze, hogy a mintaprogramok nem rövid idejü, részmunkaidős, hanem hosszabb időtartamú (12 hónapos) és teljes munkaidős foglalkoztatási lehetőséget teremtenek a rászorulók számára.

A harmadik, s témánk szempontjából legfontosabb új elem, hogy a mintaprogramokban hangsúlyosan megjelent a mezőgazdasági tevékenység. A hagyományosnak mondható településüzemeltetési munkák mellett - csatornák karbantartása, útkarbantartás - ugyanis e hátrányos helyzetü települési és térségi körben lehetővé vált mezőgazdasági, illetőleg helyi sajátosságokra építő programok ${ }^{6}$ megvalósítása. Ezen értékteremtő közfoglalkoztatási programok közvetlenül növénytermesztési, illetve állattartási tevékenységet jelentenek, amelyek természetbeni hozzájárulást biztosítanak a helyi közétkeztetés számára. Az értékteremtő közfoglalkoztatási programok másik jellemző, de kisebb jelentőségű vonulata ipari jellegü: e körben jellemzően betonelemeket, drótfonatokat készítenek.

A közfoglalkoztatási program keretében előállított árukat jellemzően nem értékesítik a piacon, hiszen döntő mértékben a közétkeztetésben, illetve a településüzemeltetésben hasznosulnak a megtermelt, illetve eloállított áruk. A szezonalitás szükségessé teszi az áruk tartósítását, feldolgozását, ami egyes településeken már egészen komoly kisüzemek - malom, vágópont, léüzem, tésztaüzem ${ }^{7}$-létrejöttéhez vezetett. A volumen növekedésével párhuzamosan megfigyelhető, hogy egyre több települési önkormányzat vág bele az előállított áru értékesítésébe. Ez részben szükségszerü, hiszen a megtermelt volumen sok esetben meghaladja a helyi közétkeztetés igényeit $\mathrm{s}$ a többletet jellemzően szociális, termelői bolton, ${ }^{8}$ esetleg termelői piacon keresztül értékesítik, de arra is találni példát, hogy az önkormányzat kiskereskedelmi láncnak ${ }^{9}$ szállít. A helyzet nyilvánvalóan konfliktussal terhelt - egyrészt az állam szeretné elkerülni, hogy támogatásból eloállított termék a támogatást nem kapó termelő helyzetét rontsa, másrészt viszont ösztönözni szeretné, hogy a mintaprogramok önfenntartóvá váljanak, s megálljanak a saját lábukon.

A probléma nem csupán Magyarországon jelentkezik, a világ többi agrárvonatkozású közfoglalkoztatási programjában is hasonló dilemma fogalmazódik 
1. ábra: A hátrányos helyzetű települések (fent), kistérségek és járások (lent), ahol kistérségi startmunka-mintaprogramok indítására van mód Disadvantaged Hungarian areas and municipalities where launching exemplary public work programs has been permitted

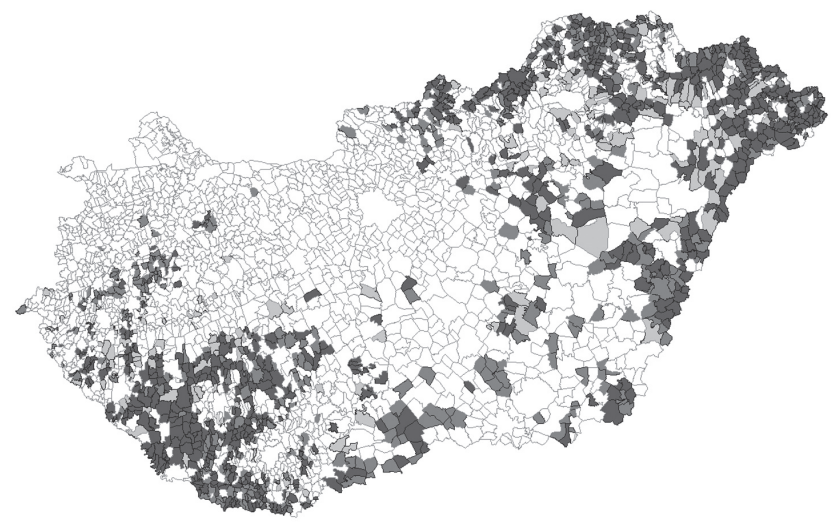

Társadalmi-gazdasági, infrastrukturális szempontból kedvezményezett (782) Jelentős munkanélküliséggel sújtott

Mindkét szempontból kedvezményezett

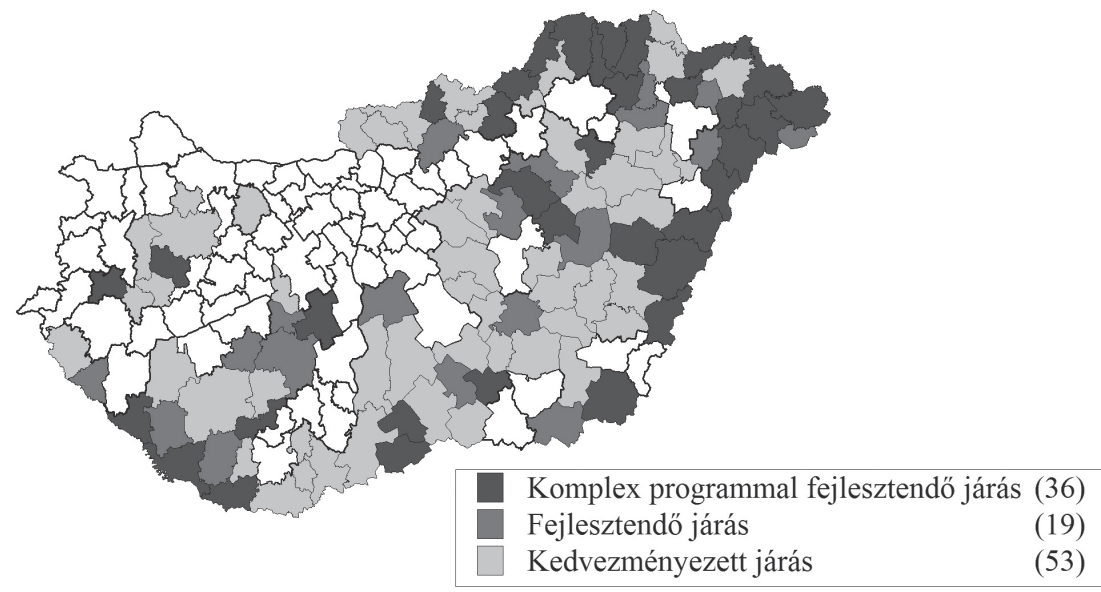

Forrás: saját szerkesztés a 290/2014. (XI. 26.) kormányrendelet, illetve a 105/2015. (IV. 23.) kormányrendelet alapján.

meg. Jellemzően nagy hangsúlyt helyeznek a piaczavarás elkerülésére, azaz arra, hogy a támogatásból létrehozott mezőgazdasági áruk ne versenyezzenek piaci alapon megtermelt javakkal. Argentínában a Világbank hiteléből megvalósított program esetében ezt sikerült elérni, hiszen a közösségi kertekben megtermelt árukat közkonyhák ellátására fordították, közvetlen piaci értékesítésre nem került sor. Ezt megkönnyítette, hogy rendkívüli kevés embert mozgósított a programelem, s alacsony volt a közösségi kertek száma is. India 
esetében a direkt mezőgazdasági termelés jóval nagyobb jelentőségü: a Mahatma Gandhi nemzeti vidéki foglakoztatási garanciatörvény keretein belül emberek millióit érinti, de a mezőgazdasági termelés alapvetően szociális célokat, mélyszegénységben élők élelmezésének javítását szolgálja. Ugyanakkor látható, hogy nincs olyan mechanizmus, amely korlátozná, hogy az érintettek értékesítsék a támogatás révén előállított zöldségeket, gyümölcsöket, amivel nyilván zavarhatják a piaci szereplőket. Magyarországon a kérdés mind élesebben jelentkezik, s egyelőre nem látható a megoldás. Kormányzati törekvés tapasztalható ugyan a közfoglalkoztatás irányából a szociális gazdaság felé terelni az érintetteket, de a jelenleg preferált szociális szövetkezeti modell nem igazán vonzó az önkormányzatok számára. Ennek hátterében az alábbiak állnak: az önkormányzati tulajdonban lévő eszközök (munkagép, eszközök) átadása, a szövetkezeti tagok felvétele és kiléptetése, a döntéshozatali mechanizmus, a tagi kockázatviselés és a bizonytalannak ítélt értékesítési lehetőségek.

A piaczavarás nem csupán a termékpiacon értelmezheto", hanem a munkaerőpiacon is - általános elvárás a közfoglalkoztatási programokkal szemben, hogy a támogatás ne zavarja meg a munkaerőpiacot, ne generáljon bérversenyt a támogatott és a piaci munkahelyek közt, illetve ne fenyegesse a piaci munkaerő-kereslet kielégítését. Ez a gyakorlatban azt jelenti, hogy a közpolitika formálója a közfoglalkoztatási programok keretfeltételeit úgy próbálja meghatározni, hogy a feltételek ne legyenek túl vonzóak, a résztvevők „,ne ragadjanak benn” ezeken a másodlagos munkaerő-piaci helyeken, ${ }^{10}$ hanem váljanak alkalmassá és legyenek érdekeltek az elsődleges munkaerőpiacon való elhelyezkedésre, ugyanakkor ne kínáljanak túl kedvezőtlen feltételeket se, mert akkor a politikai cél elérése nem biztosítható.

Ez a cél a legkedvezőtlenebb helyzetű térségekben, ahol a piaci erők nem képesek megfelelő számú munkahelyet teremteni, korántsem magától értetődo”, az érintettek számára ugyanis számos vonzó tulajdonsággal bír a konstrukció. A közfoglalkoztatottak számára fontos vonzerőt jelent a hosszú időtartamú, ${ }^{11}$ nyolcórás foglalkoztatás, amely valódi, kézzel fogható, a közösség tagjai számára is látható eredményre vezet, ,jóval nagyobb becsülete van, mint a szemétszedésnek". A közfoglalkoztatón ${ }^{12}$ számára pedig vonzerőt jelent, hogy nem csupán a közfoglalkoztatottak bérköltségét fedezi a program teljes mértékben, de a tevékenységhez közvetlenül szükséges eszközök, anyagok beszerzésére is bizonyos mértékig (a bevont létszám függvényében a közvetlen költségek 70-100\%-áig) fedezetet nyújt.

A „beragadási veszély” korántsem tekinthető megalapozatlannak: a hátrányos helyzetủ településeken, térségekben megvalósuló mezőgazdasági programokban részt vevők havi átlagos létszáma tartósan magas, sőt emelkedő tendenciát mutat (2. ábra). Ez egyrészt a konstrukció sikerességének is betudható, másrészt a hátrányos helyzetű településeket sújtó kiúttalanságra is rámutat, ahol piaci munkavállalási lehetőségek hiányában a minimálbért el nem érő fizetésért emberek tízezrei dolgoznak. 
2. ábra: A mezőgazdasági közfoglalkoztatási programokban részt vevők havi átlagos létszáma 2013-2015 között

Monthly average number of agricultural public workers in Hungary (2013-2015)

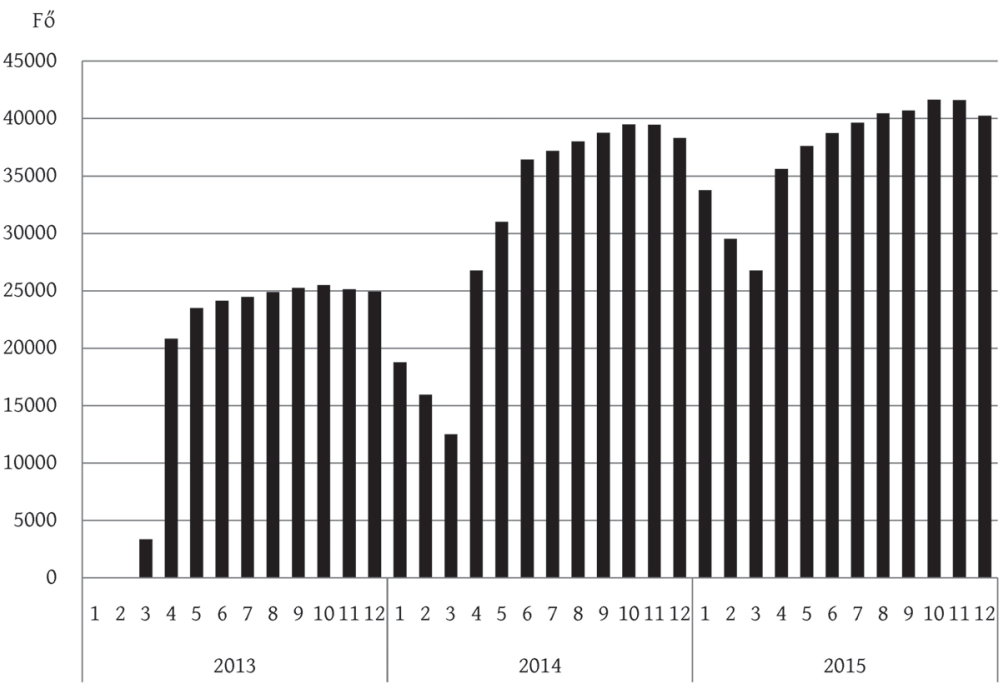

Forrás: saját szerkesztés a Belügyminisztérium havi közfoglalkoztatási jelentései alapján.

A mezőgazdasági közfoglalkoztatási programok területileg rendkívül erős koncentráltságot mutatnak (3. ábra): a 2014-es adatok alapján (BM 2015) a programban dolgozók közel fele a tiszántúli megyékben (Szabolcs-Szatmár-Bereg, Hajdú-Bihar, Békés, illetve Jász-Nagykun-Szolnok megye) él. Nagyon fontos

3. ábra: A mezőgazdasági közfoglalkoztatási programokban dolgozók átlagos havi létszáma 2015-ben Monthly average number of agricultural public workers in 2015

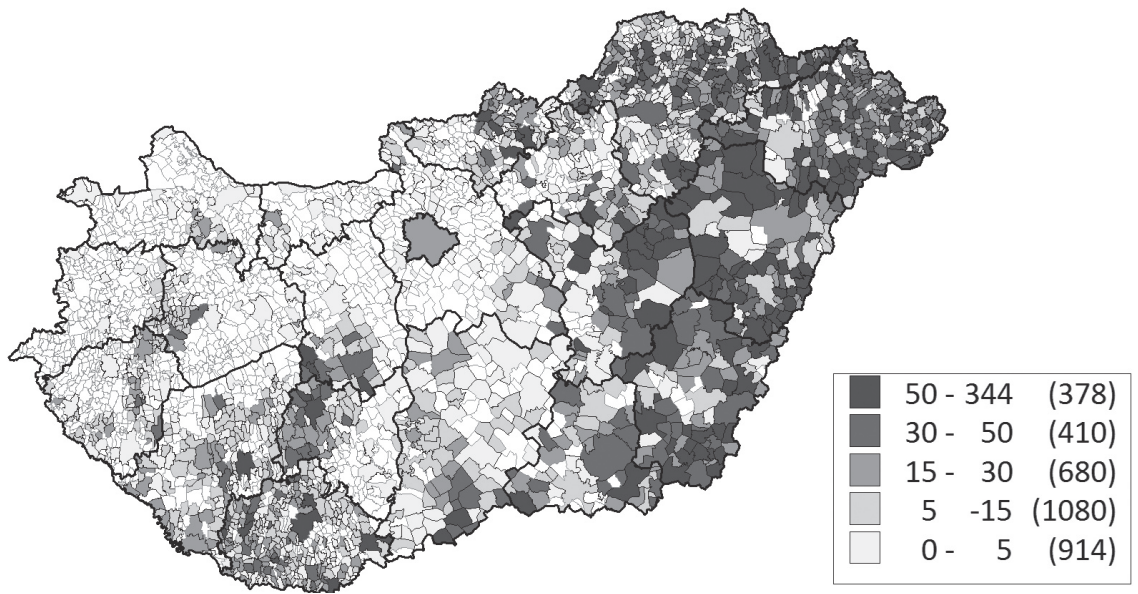

Forrás: saját számítás és szerkesztés a BM adatai alapján. 
rámutatni arra, hogy a mezőgazdasági jellegű közfoglalkoztatási programok új elemet jelentenek, de alapvetően kiegészítő jellegüek. A legfrissebb teljes körü adatok alapján (BM 2015) az összes közfoglalkoztatott közel háromnegyede (73\%) hátrányos helyzetü településen élt 2014-ben, azaz olyan településen, ahol jogosultak voltak kistérségi, járási startmunka-mintaprogramot indítani, ennek ellenére is a mezőgazdasági programelemben dolgozók aránya országosan csupán 17 százalék volt. Vagyis a mezőgazdasági közfoglalkoztatás fontos, de a közfoglalkoztatás rendszerén belül országosan korántsem meghatározó elem. Ahogyan az a 4. ábrán látható, települési szinten jelentős a differenciáltság, hiszen egyes településeken a mezőgazdasági közfoglalkoztatás meghatározó közfoglalkoztatási elem lehet. Aligha meglepő, ha legnagyobb jelentőségre Baranya, Tolna, Somogy, Szabolcs-Szatmár-Bereg, illetve Borsod-Abaúj-Zemplén megye aprófalvas területein tett szert a mezőgazdasági közfoglalkoztatás, míg a nagyobb lélekszámú, nagy határú alföldi településeken, ahol számszerủleg a legtöbb közfoglalkoztatott található, jelentősége jóval kisebb, hiszen ott az egyéb közfoglalkoztatási programokban is sokan dolgoznak.

A mezőgazdasági közfoglalkoztatási programok megvalósításában komoly korlátozó tényezőt jelent, hogy egyrészt a közfoglalkoztatónak elsősorban saját tulajdonban álló földterületen kell megvalósítania a programot, másrészt hogy a programba bevont földterület nagysága meghatározza a maximálisan bevonható közfoglalkoztatottak számát. ${ }^{13} \mathrm{Ez}$ egyben azt jelenti, hogy a mezőgazdasági közfoglalkoztatás lehetőségeit behatárolja a közfoglalkoztató - leggyakrabban a települési önkormányzat - tulajdonában álló mezőgazdasági terület nagysága. Így azokon a településeken tehet szert nagy jelentőségre a mezőgazdasági közfoglalkoztatás, ahol a közfoglalkoztatottak száma viszonylag alacsony és az ön-

4. ábra: A mezőgazdasági közfoglalkoztatási programokban dolgozók aránya az összes közfoglalkoztatotthoz mérten 2015-ben

The percentage of agricultural public workers in proportion to the total public works employees in 2015

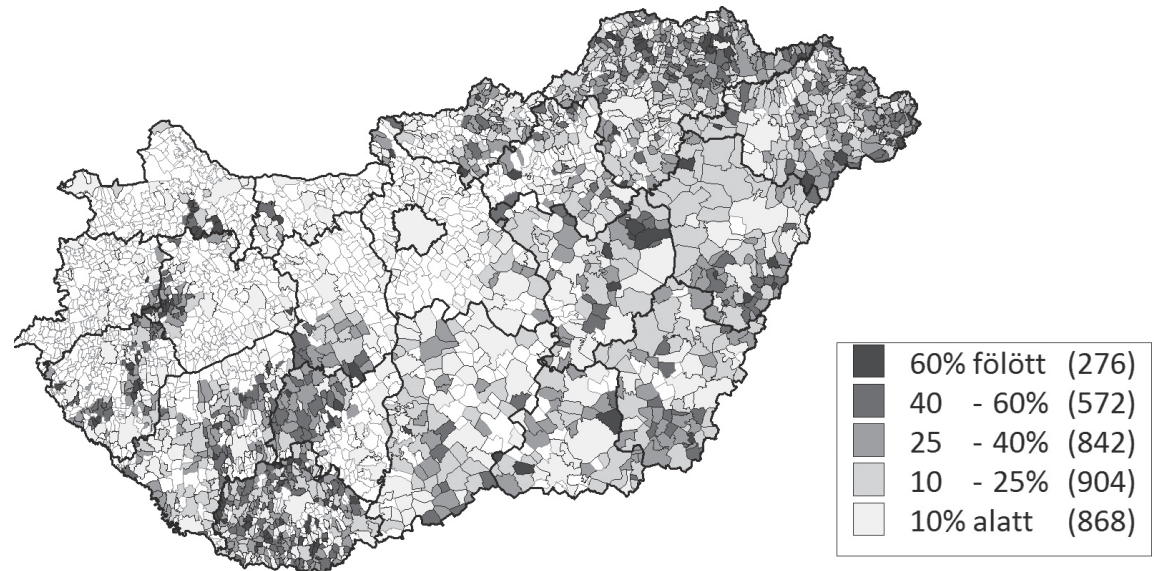

Forrás: saját számítás és szerkesztés a BM adatai alapján. 
kormányzat rendelkezik hasznosítható földtulajdonnal, ami az aprófalvas térségek településein gyakrabban előfordul. A földterület növelésével az önkormányzatok elvileg növelhetnék a mezőgazdasági közfoglalkoztatásba bevonható személyek számát, de a mezőgazdasági földek forgalmáról szóló 2013. évi CXXII. törvény alapján a települési önkormányzatok földhasználati és hasznosítási jogot nem szerezhetnek, ${ }^{14}$ így ez a lehetőség 2014-től nem áll fenn.

\section{A mezőgazdasági közfoglalkoztatottak szociodemográfiai jellemzői}

A mezőgazdasági közfoglalkoztatottak köréről teljes körü adatokat egyetlen nyilvánosan elérhető publikáció, a Belügyminisztérium által kiadott Beszámoló a 2014. évi közfoglalkoztatásról című kiadvány közöl (BM 2015). A továbbiakban építünk a 2011 és 2013 közt felvett közfoglalkoztatotti adatokra is, amelyek a Nemzeti Munkaügyi Hivatal által működtetett Foglalkoztatási és Közfoglalkoztatási Adatbázis (FOKA) egyedi adataiból származnak, ${ }^{15}$ és legfontosabb hozzáadott értéküknek az tekinthető, hogy információt szolgáltatnak a közfoglalkoztatottak elhelyezkedési lehetőségeiről.

A mezőgazdasági közfoglalkoztatási programokba bevont személyek több olyan demográfiai és szociális sajátossággal bírnak, amelyekkel elkülönülnek egyrészt az elsődleges munkaerőpiacon foglalkoztatottak, másrészt pedig a közfoglalkoztatottak teljes csoportjától. Az első fontos eltérés, hogy a mezőgazdasági programokban felülreprezentáltak a nők (53,7\%), ami annak fényében feltétlenül kiemelendő, hogy 2014-ben mind a foglalkoztatottak (45,9\%), mind a közfoglalkoztatottak (45,8\%), mind pedig a mezőgazdaságban foglalkoztatot$\operatorname{tak}^{16}(25,9 \%)$ körében jóval alacsonyabb volt a részesedésük.

A résztvevők kor szerinti megoszlását megvizsgálva (3. táblázat) látható, hogy a mezőgazdasági közfoglalkoztatási programok résztvevői egy korcsoportban, a 25 év alatti fiatalok esetében mutatnak markáns eltérést az elsődleges munkaerőpiacon foglalkoztatottakhoz képest. A kistérségi mintaprogramok résztvevőinek tizede a 25 évnél fiatalabbak közül kerül ki, ami messze meghaladja a foglalkoztatottak körében tapasztalható (6,4\%) arányt,

3. táblázat: A közfoglalkoztatottak és a teljes foglalkoztatotti kör korcsoportok szerinti megoszlása 2014-ben

The distribution of workers, public workers and agricultural public workers by age groups in Hungary (2014)

\begin{tabular}{lccccc}
\hline \multicolumn{1}{c}{ Csoport } & 25 év alatt & 25-34 év & 35-44 év & 45-54 év & 55 év és felette \\
\hline Foglalkoztatottak & 6,4 & 22,9 & 31,3 & 24,4 & 15,0 \\
Közfoglalkoztatottak & 14,6 & 21,2 & 25,0 & 25,7 & 13,6 \\
Mezőgazdasági közfoglalkoztatottak & 11,7 & 20,8 & 27,0 & 27,1 & 13,4 \\
\hline
\end{tabular}

Forrás: BM 2015, 8. és 29. táblázat adatai alapján saját számítás. 
mutatva, hogy sok fiatal közfoglalkoztatási programokban szerzi első munkatapasztalatait.

A fiatal korosztály nagyobb arányú közfoglalkoztatási részesedésében feltételezhetően szerepet játszik, hogy éppen a hátrányos helyzetü térségekben alacsonyabbak az iskolai végzettség mutatói, s alacsonyabb a továbbtanulási hajlandóság, így a fiatal korosztályhoz tartozók nagyobb arányban jelennek meg a munkaerőpiacon. A 4. táblázat világosan mutatja azt az elképesztő méretű szakadékot, amely a mezőgazdasági közfoglalkoztatottak és a nyílt munkaerőpiacon foglalkoztatottak iskolai végzettsége közt tátong. A foglalkoztatottak teljes csoportjában alig $11,2 \%$ rendelkezett legfeljebb általános iskolai végzettséggel, miközben a közfoglalkoztatottak körében ez az arány meghaladta az 55\%-ot is.

A közfoglalkoztatási programok képzési komponense az érintett munkaerő drámaian alacsony képzetségi szintjét kívánta emelni. A TÁMOP 2.1.6 - Újra tanulok! elnevezésű kiemelt projektben 2012 őszén kezdődtek meg a nagy létszámot érintő képzések a Türr István Képző és Kutató Intézet bevonásával. A TÁMOP 2.1.6. program kifutása után a GINOP 6.1.1. - Alacsony képzettségüek és közfoglalkoztatottak képzése címet viselő kiemelt projekt keretein belül folytatódnak a közfoglalkoztatottakat bevonó képzések. A képzések célja kettős: egyrészt a közfoglalkoztatottakat kívánja betanítani a mezőgazdasági közfoglalkoztatási munkák elvégzésére, másrészt pedig olyan hasznosítható tudást szeretne átadni, amelynek révén az érintettek őstermelővé, illetve szociális szövetkezeti dolgozóvá válhatnak a közfoglalkoztatásból való kikerülésük után (ÁSZ 2013). Témánk szempontjából a kistérségi startmunkaprogramok esetében

4. táblázat: A közfoglalkoztatottak száma és megoszlása pillérenként, iskolai végzettség szerint, 2014

The number and distribution of public workers by public works programs types and educational level in 2014

\begin{tabular}{|c|c|c|c|c|c|c|}
\hline Közfoglalkoztatási pillér & $\begin{array}{l}\text { Legfeljebb } \\
\text { általános } \\
\text { iskola }\end{array}$ & $\begin{array}{l}\text { Szakmun- } \\
\text { kás, szak- } \\
\text { iskola }\end{array}$ & $\begin{array}{l}\text { Szakkö- } \\
\text { zépiskola, } \\
\text { gimná- } \\
\text { zium }\end{array}$ & Felsőfok & Összesen & Összesen \\
\hline & & & százalék & & & $f_{0}^{\prime \prime}$ \\
\hline $\begin{array}{l}\text { Mezőgazdasági program (a kistér- } \\
\text { ségi startmunka-mintaprogramo- } \\
\text { kon belül) }\end{array}$ & 55,2 & 30,1 & 13,8 & 1,0 & 100 & 31050 \\
\hline $\begin{array}{l}\text { Kistérségi startmunka-mintaprog- } \\
\text { ramok összesen }\end{array}$ & 56,0 & 29,8 & 13,3 & 1,0 & 100 & 59290 \\
\hline $\begin{array}{l}\text { Országos közfoglalkoztatási progra- } \\
\text { mok }\end{array}$ & 44,0 & 30,4 & 21,2 & 4,3 & 100 & 30921 \\
\hline $\begin{array}{l}\text { Hosszabb időtartamú közfoglalkoz- } \\
\text { tatás }\end{array}$ & 54,7 & 26,3 & 16,9 & 2,1 & 100 & 88639 \\
\hline Összes közfoglalkoztatási program & 53,3 & 28,1 & 16,5 & 2,1 & 100 & 178850 \\
\hline Foglalkoztatottak összesen & 11,2 & 28,3 & 33,8 & 26,6 & 100 & - \\
\hline
\end{tabular}

Forrás: BM 2015, 13. és 30. táblázat adatai alapján saját számítás. 
kötelező képzések három csoportja releváns: a háztáji növénytermesztés és tartósítás (18 hónap), a háztáji állattartás (12 hónap), illetve a háztáji növénytermesztés és állattartás (24 hónap). Fontos rámutatni arra, hogy a megvalósított képzések az elsődleges munkaerőpiacon való elhelyezkedési lehetőségeket nem bővítik érdemben, inkább a ház körüli növénytermesztés beindítását segítik, esetleg javítják a szociális szövetkezetek létrehozásának, működtetésének esélyeit. A mezőgazdaságban is egyre inkább érzékelhető a képzett munkaerő - például mezőgazdasági gépkezelő, nehézgépkezelő - iránti kereslet erősödése, ám a közfoglalkoztatási programok képzési része nem az árutermelő nagyüzemi mezőgazdaság munkaerő-keresletére reflektál, hiszen a közfoglalkoztatásból kikerülők legfeljebb betanított mezőgazdasági szezonmunkák elvégzésére készek. A képzési kínálat egyoldalúsága ugyanakkor a magyar mezőgazdaság strukturális gyengeségére is reflektál, hiszen a fejletlen és mindinkább háttérbe szoruló munkaerő-intenzív tevékenységek (állattartás, zöldségtermesztés) fejlesztését segítik a tudásbázis szélesítésével. Sajátos módon a kistérségi startmunkaprogramok a vidéki életmód fennmaradásához is hozzájárulnak, újraélesztve, fenntartva a háztáji gazdálkodást - ha nem is a teljes lakosság, de a leginkább rászorulók körében.

E ponton érdemes rámutatni arra, hogy a mezőgazdasági közfoglalkoztatás több szállal kapcsolódik a szociális földprogramokhoz. Az 1990-es évek elején a legkedvezőtlenebb helyzetü települések számára létrehozott program nem a reménytelenül kedvezőtlen foglalkoztatási helyzetet, hanem a mélyszegénységet kívánta orvosolni, természetbeni szociális ellátásként vetőmagvakat, háziállatokat (sertés, tyúk) biztosítva a programban résztvevőknek (Bartal, Sziklai 2006; Rácz 2013). Bár a program költségvetése meglehetősen szerény (évi 2-300 millió $\mathrm{Ft}$ ) mégis több ponton kapcsolódik a kistérségi startmunkaprogramokhoz. Egyrészt mindkét program a legkedvezőtlenebb helyzetű településeket kedvezményezi, másrészt pedig mindkét program a mezőgazdaság - vagy még inkább a háztáji gazdálkodás - felé kívánja terelni az érintetteket, javítva megélhetési lehetőségeiket. Tereptapasztalatok arra mutatnak, hogy a szociális földprogramban részt vevő települések a kistérségi startmunkaprogramokban is aktívabbak, innovatívabban állnak a lehetőségekhez, minden lehetséges támogatási eszközt megragadnak a foglalkoztatási lehetőségek bővítéséhez, az eszközállomány fejlesztéséhez.

\section{Elhelyezkedési lehetőségek}

A közfoglalkoztatási program meglehetősen óvatos a célkitűzéseket illetően, mintha a közpolitika formálója is tisztában lenne azzal, hogy az Út a munkához program tapasztalatai (Scharle 2011) alapján a hátrányos helyzetű térségekben az elsődleges munkaerőpiacra való visszatérésnek nem az aktív korúak hozzá- 
állása, tapasztalatlansága a legfőbb akadálya, hanem a munkaerö-piaci lehetőségek hiánya. Mind az Út a munkához (Scharle 2011; Váradi 2010), mind pedig a közfoglalkoztatási programok értékelése (Cseres-Gergely, Molnár 2014; Molnár, Bakó, Cseres-Gergely, Kálmán, Szabó 2014), arra mutatott rá, hogy a programok lebonyolítását követően a résztvevők csekély része tud csak elhelyezkedni az elsődleges munkaerőpiacon, nagy a valószínűsége, hogy a résztvevő újból valamilyen közfoglalkoztatási programban tűnik fel. A vizsgált időszak első évében (2011. IV. negyedévtől 2012. III. negyedévig) a közfoglalkoztatási programok lezárultát követő 180. napon a résztvevők 17,2 százaléka, egy évvel később (2012. IV. negyedévtől 2013. III. negyedévig) pedig már csak 12,8 százaléka volt foglalkoztatott az elsődleges munkapiacon (Cseres-Gergely, Molnár 2014), azaz meglehetősen szűk körben érvényesült a munka világába való visszavezetés.

Molnár és szerzőtársai (2014) feltárták azt, hogy a közfoglalkoztatásból kikerülők elhelyezkedési esélyei akkor a legrosszabbak, ha az ország hátrányos helyzetü térségeiben élnek, alacsony iskolai végzettségűek, a közfoglalkoztatást az önkormányzatok szervezik hosszabb időtartamra és egyszerü betanított jellegű munkát kell végezni. A felsorolt jellemzők sajnálatosan pontosan illenek a mezőgazdasági közfoglalkoztatási programokra, így aligha csodálkozhatunk, ha a kistérségi startmunkaprogramok résztvevői körében még alacsonyabb az elsődleges munkaerőpiacon elhelyezkedők aránya. Míg a teljes közfoglalkoztatotti kör esetében Molnár és munkatársai úgy találták, hogy a nyers kilépési ráta 17,2\% volt, a mezőgazdasági programokban résztevők körében ez csupán 9,9\%-ot ért el, azaz a közfoglalkoztatottak alig tizede tudott az elsődleges munkaerőpiacon megélhetést találni.

A mezőgazdasági közfoglalkoztatottak döntő része (65\%) a rendszerben maradt és újból valamilyen közfoglalkoztatási programban dolgozott. A nemek szerinti megoszlást vizsgálva (5. ábra) látható, hogy a férfiak körében némileg magasabb azok aránya, akik piaci foglalkoztatást találtak (11,3\% a 9\%-kal szemben), míg a nők között az újból közfoglalkoztatásba kerültek aránya magasabb (68,8\% a 59,4\%-kal szemben).

A fenti eredmények tükrében érdekes kérdést jelent, hogy milyen tényezők, egyéni jellemzők segítették a közfoglalkoztatottak elsődleges munkaerőpiacon való elhelyezkedését. Probit regressziós modellel (5. táblázat) becsültem, hogy a legelemibb tényezők, mint a közfoglalkoztatottak neme (nemeKF) életkora (kshkorcsKF) és iskolai végzettsége (iskvegzKF) milyen hatást gyakorolnak az elsődleges munkaerő-piaci elhelyezkedés esélyére. Azt mondhatjuk, hogy az elsődleges munkaerőpiacon való elhelyezkedés esélyét csökkenti az életkor emelkedése, növeli viszont az iskolázottság. A közfoglalkoztatott neme is befolyásoló erővel bír, a férfiak esetében nagyobb az elhelyezkedés valószínűsége. Leegyszerűsítve tehát az ország hátrányos helyzetü térségeiben, településein megvalósított mezőgazdasági közfoglalkoztatási programokból kikerülő embereknek annál jobb a munkaerő-piaci helyzete, minél iskolázottabbak, minél fiatalabbak és lehetőség szerint férfiak. Tekintve, hogy a mezőgazdasági közfog- 
5. ábra: A közfoglalkoztatási program lezárultát követő 180. napon az érintettek nemek és munkaerőpiaci státusz szerinti megoszlása (\%), a 2011-2013. évi NMH FOKA-adatbázis egyedi adatai alapján Ex public workers by gender and employment status, six months after the end of their participation in the programme (\%)

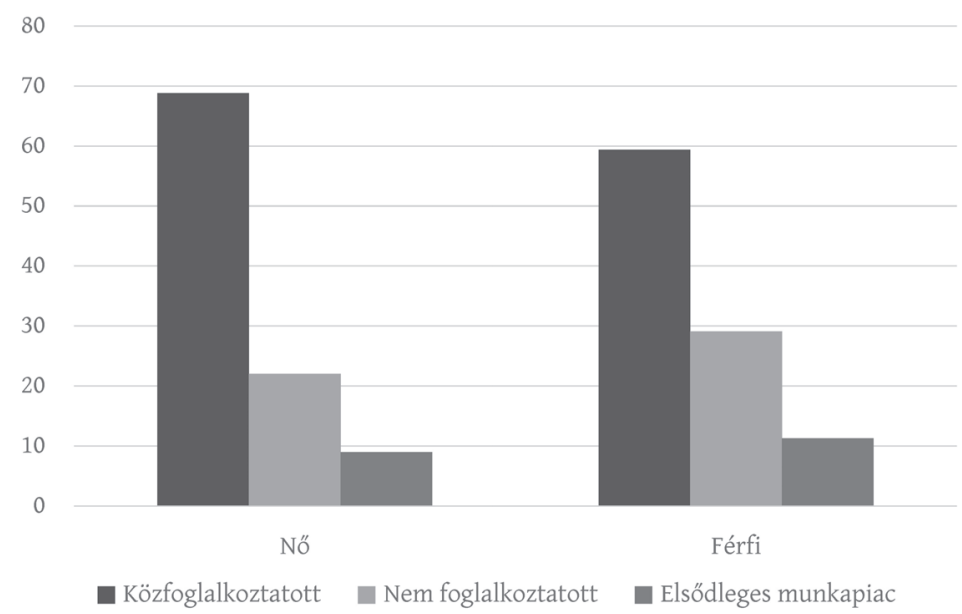

Forrás: saját számítás és szerkesztés.

lalkoztatottak nagyobb része nő és legfeljebb általános iskolát végzett, aligha meglepő a nyílt piaci foglalkoztatásba kerülés alacsony szintje.

Az eredmények rímelnek a foglalkoztatáspolitika alapvetéseire - a munkaerőpiacon hátrányt szenvednek a nők, idősek és képzetlenek -, e tekintetben újdonság nem fedezhető fel. Rá kell mutatni ugyanakkor arra, hogy a probit regressziós becslés alapján a mezőgazdasági közfoglalkoztatási programokban dolgozók esetében az iskolai végzettség emelkedése önmagában csekély mértékben befolyásolja a piaci elhelyezkedési esélyeket, a hátrányos helyzetü térségekben a képzettebb közfoglalkoztatottak is hajlamosak beragadni a hosszabb időtartamú foglalkoztatási lehetőséget nyújtó programokba. Tereptapasztalatok alapján ennek hátterében két tényező húzódhat meg. Egyrészt a mezőgaz-

5. táblázat: A mezőgazdasági közfoglalkoztatási programban részt vevők munkapiacra való kilépési esélyeire ható tényezők a probit regressziós becslés alapján

Factors affecting agricultural work program participants' chance to enter the primary labor market. Parameter estimation, standard errors and probabilities of probit regression

\begin{tabular}{lrcrrrr}
\hline \multicolumn{1}{c}{ Mutató } & Együttható & Standard hiba & $z$ & $P>|z|$ & \multicolumn{2}{c}{$95 \%$-os konfidenciaintervallum } \\
\hline iskvegzKF & 0,1238329 & 0,0077098 & 16,06 & 0,000 & 0,108722 & 0,1389437 \\
kshkorcsKF & $-0,0362776$ & 0,0056557 & $-6,41$ & 0,000 & $-0,0473627$ & $-0,0251925$ \\
nemeKF & 0,1008972 & 0,0255184 & 3,95 & 0,000 & 0,050882 & 0,1509124 \\
konstans & $-1,507864$ & 0,0468459 & $-32,19$ & 0,000 & $-1,59968$ & $-1,416047$ \\
\hline
\end{tabular}

Megfigyelések száma = 18952; $\operatorname{LR}_{\text {chi }}{ }^{2}(3)=353,09 ;$ Prob > chi2 = 0,0000; Log likelihood = -5988,3837; Pszeudo $R^{2}=$ 0,0286. Forrás: az NMH FOKA 2011-2013. évi egyedi adatai alapján saját számítás. 
dasági program a közfoglalkoztatás leginkább megbecsült területe, ahová talán kockázatkerülésből is az önkormányzatok a legmegbízhatóbbnak, legszorgalmasabbnak tartott résztvevőket helyezik el. A közfoglalkoztatási programok szervezői újabb program indulásakor a korábban már bizonyított, kevés problémát jelentő, motivált embereket igyekeznek a rendszerben tartani. Másrészt pedig feltételezhető, hogy a közfoglalkoztató egyes esetekben (tévedésből vagy szándékosan) mezőgazdasági közfoglalkoztatottként jelenít meg ténylegesen más munkát végző alkalmazottat.

\section{Összegzés}

A hazai foglalkoztatáspolitika évtized eleji átalakítása, a workfare jelleg erősítése alapjaiban formálta át a hazai közfoglalkoztatási rendszert. Az eredetileg átmeneti foglalkoztatást biztosító aktív foglalkoztatáspolitikai eszközből egy univerzális, majd minden álláskereső számára elérhető, majdhogynem garantált elhelyezkedési lehetőség vált. A segély helyett munka elvének érvényesítése nagyszámú új, különösebb szakértelmet nem igénylő támogatott munkahely teremtését követelte meg, amire a vidéki térségekben a mezőgazdaság kínálkozott természetes megoldásként.

A közfoglalkoztatás új rendszerében kiemelt szerep jutott az értékteremto", s ezen belül is a mezőgazdasági programoknak. A mezőgazdasági programban való részvétel az érintettek számára ugyan a minimálbérnél alacsonyabb fizetést, de hosszabb, nemritkán lényegében tartós foglalkoztatást és biztos, rendszeres bevételt jelent, így nem egy esetben az idénymunka és az ingázással járó elhelyezkedés alternatívájává vált. A településvezetők nemcsak azért üdvözlik a programot, mert alapvetően elfogadják a workfare filozófiáját és gyakorlatát, hanem mert a startmunka a helyi fejlesztések jószerivel kizárólagos forrásává vált, sokszor a legfőbb foglalkoztatóvá válva.

A mezőgazdasági tevékenység - vagy kicsit tágabban a közfoglalkoztatás - fizikai termékek eloállításával való összekapcsolása nemzetközi szinten ritka, de nem példa nélküli. Argentínában és Indiában, ahol a közfoglalkoztatási programok keretében mezőgazdasági tevékenységek is megjelentek, hivatalosan nem kerülnek piaci forgalomba a megtermelt mezőgazdasági termékek, hanem a rászorulók étkeztetésére használják fel azokat. A hazai gyakorlat e tekintetben legalábbis kétarcú, hiszen határozott elvárás a piaczavarás elkerülése, ugyanakkor cél a fejlesztési projektek saját lábra állása, önfenntartóvá válása, ami végső soron a valódi piacra való kilépést jelenti. Az önállóvá válás központilag preferált útja a szociális szövetkezetek létrehozása, amelyet az érintett települési önkormányzatok nem tekintenek vonzó lehetőségnek. A tapasztalatok szerint a települési önkormányzatok több megfontolásból ódzkodnak e szociális szövetkezetek létrehozásától. Nem látják biztosítottnak a 
piaci megkapaszkodás lehetőségét, nem szívesen adják át a startprogram keretében felhalmozott jelentős eszközállományt a szövetkezet számára, a közfoglalkoztatottakat sem tartják alkalmasnak arra, hogy felelős tagokká váljanak (akik ugyanolyan szavazati joggal rendelkeznének a szövetkezetben, mint a polgármester). Az empirikus kutatási eredmények alapján azt mondhatjuk, hogy jelentős állami és/vagy uniós források, valamint ösztönzők hiányában nem számolhatunk a közfoglalkoztatásból kisarjadó szociális szövetkezetek látványos bővülésére. Ami ugyanakkor arra is felhívja a figyelmet, hogy a startmunkaprogramok fennmaradása, fenntarthatósága alapvetően az állami támogatáson múlik.

\section{Köszönetnyilvánítás}

A tanulmány elkészültét az OTKA Földből élők: agrárszereplők, vidéki fejlődési pályák és vidékpolitikák Magyarországon címü, 100675 számú projekt támogatta.

\section{Jegyzetek}

1 A kozfoglalkoztatas.bm.hu adatai alapján.

2 A fizetett munkaerő nem tartalmazza a családi munkaerőt, akik nem fizetést kapnak, hanem a tevékenység eredményéből (nyereség) részesülnek.

3 A kormányzat ugyan elkészítette a Közfoglalkoztatási koncepció 2012-2014 című dokumentumot, ám ez a nyilvánosság számára nem elérhető (ÁSZ 2013), így csupán a vonatkozó törvényre (2011. évi CVI. törvény) és a kormányzati szereplők kommunikációjára hagyatkozhatunk. A törvény preambuluma alapján „Az Országgyűlés az értékteremtő közfoglalkoztatás jogi kereteinek megteremtése és a munkaképes lakosság munkához juttatása, az álláskeresők foglalkoztatásának elősegítése érdekében az alábbi törvényt alkotja."

4 A hátrányos helyzetű kistérségek körét a 311/2007. (XI. 17.), a kedvezményezett járások körét a 290/2014. (XI. 26.) kormányrendelet határozza meg, egyedi miniszteri döntés alapján három további (téti, gyulai, pécsi) kistérségben indulhattak programok.

5 A hátrányos helyzetü települések körét előbb a 240/2006. (XI. 30.), majd pedig a 105/2015. (IV. 23.) kormányrendelet határozta meg. Azon települések, amelyek a kormányrendelet alapján nem jogosultak mintaprogram indítására, a megyei kormányhivatalok decentralizált kereteiből, egyedi döntések alapján hosszabb időtartamú közfoglalkoztatási programokat indíthatnak.

62011 és 2014 közt téli és egyéb értékteremtő programelem is müködött. 2014-től ez önálló elemként megszünt s a tevékenység a helyi sajátosságokra épülő program részeként végezhető.

7 Garadna településen jött létre tésztaüzem, Jánoshidán malom működik, Gyulajon pedig húsfeldolgozó.

8 Szarvas településen 2014-ben termelői boltot alakítottak ki a helyi piacon a felesleg értékesítésére.

9 2013-tól Ásotthalom településről édesburgonyát szállítottak a CBA, a G’Roby és az Aldi kiskereskedelmi láncnak.

10 A 2011-es Nemzeti társadalmi felzárkóztatási terv a foglalkoztatás három pillérét nevesíti: a nyílt piaci mellett a szociális gazdaságot és a közfoglalkoztatást. 
11 A hosszabb időtartam 2011-től 2013-ig legfeljebb 12 hónapot, 2014-ben legfeljebb 11 hónapot jelentett, 2015-től ismét 12 hónap lett, de ezt legfeljebb további 6 hónappal lehet meghosszabbítani.

12 A 2011. évi CVI. törvény 1. § (3) alapján közfoglalkoztató lehet (egyebek mellett) helyi és nemzetiségi önkormányzat, költségvetési szerv, egyházi jogi személy, közhasznú jogállású szervezet, civil szervezet.

13 Egy hektár földterületen alapesetben hat fő foglalkoztatása tervezhető, bár ettől fóliasátrak, üvegházak s egyéb intenzív rendszerek esetében el lehet térni.

14 Kivételt jelentenek a Nemzeti Földalapról szóló 2010. évi LXXXVII. törvény szerint a települési önkormányzatok ingyenes vagyonkezelésébe adott földek, valamint az egy hektárnál nem nagyobb területű tanyák, amelyek a közfoglalkoztatási programok lebonyolítását segíthetik (2-15 év időtartamra) - a 263/2010. (XI. 17.) kormányrendelet alapján.

15 Az adatokat a Költségvetési Tanács megbízásából készített munkához (bővebben lásd Molnár, Bakó, Cseres-Gergely, Kálmán, Szabó 2014) bocsátotta rendelkezésre a Nemzeti Munkaügyi Hivatal.

16 A KSH lakossági munkaerő-felmérése szerint 2014-ben a mezőgazdaságban foglalkoztatott körében; a 2_1_7_2. Stadat-tábla alapján saját számítás.

\section{Irodalom}

ÁsZ (2007): A közmunkaprogramok támogatására fordított pénzeszközök hasznosulásának ellenőrzéséról. Az Állami Számvevőszék 0732 számú jelentése, Budapest, 2007. szeptember

ÁSZ (2013): Jelentés a közfoglalkoztatás és a hozzá kapcsolódó képzési programok támogatási rendszere hatékonyságának, eredményességének ellenőrzéséról. Az Állami Számvevőszék 13097. jelentése, Budapest, 2013. szeptember

Bartal A. M., Sziklai I. (2006): A szociális földprogramok kedvezményezettjeinek helyzete két kistérségben. Területi Statisztika, 5., 509-520.

BM (2015): Beszámoló a 2014. évi közfoglalkoztatásról. Belügyminisztérium, Közfoglalkoztatási és Vízügyi Helyettes Államtitkárság, Budapest

Czirfusz M. (2015): A közfoglalkoztatás térbeli egyenlőtlenségei. In: Fazekas K., Varga J. (szerk.): Munkaerőpiaci tükör, 2014. MTA Közgazdaság- és Regionális Tudományi Kutatóközpont Közgazdaság-tudományi Intézet, Budapest, 126-138.

Cseres-Gergely Zs., Molnár Gy. (2014): Közmunka, segélyezés, elsődleges és másodlagos munkaeröpiac. In: Kolosi T., Tóth I. Gy. (szerk.): Társadalmi Riport 2014. Tárki, Budapest, 204-225.

Csoba J. (2010): „Segély helyett munka.” A közfoglalkoztatás formái és sajátosságai. Szociológiai Szemle, 1., 26-50.

Gyáni G. (2011): Közmunka a Horthy-korban: Az állami szociálpolitika megoldási kísérletei. História, 7., 30-33.

Hamar A. (2010): Megújuló folytonosság. Közfoglalkoztatás egy észak-alföldi kistérségben. Esély, 1., 65-78.

Jalal, H. (2007): Promotion nationale: Forty-five years of experience of public works in Morocco. The Levy Economics Institute Working Paper, 524. http://www.levyinstitute.org/pubs/wp_524.pdf (Letöltés: 2016. július 20.)

Kálmán J. (2015): A közfoglalkoztatási programok háttere és nemzetközi tapasztalatai. In: Fazekas K., Varga J. (szerk.): Munkaerőpiaci Tükör, 2014. MTA Közgazdaság- és Regionális Tudományi Kutatóközpont Közgazdaság-tudományi Intézet, Budapest, 42-65.

Keynes, J. M. (1965): A foglalkoztatás, a kamat és a pénz általános elmélete. KJK, Budapest

Koltai L. (2014): A közfoglalkoztatottak jellemzői. Munkaügyi Szemle, 3., 60-69.

Lieuw-Kie-Song, M., Philip, K., Tsukamoto, M., Van Imschoot, M. (2010): Towards the right to work: Innovations in public employment programmes (IPEP). ILO Employment Sector Employment Working Paper, 69. 
Lőrincz L. (2015): A közfoglalkoztatás föbb prioritásai 2015. évben. A Vidékfejlesztés mint fenntartható fejlődés konferencián tartott előadás, Kistelek, 2015. április 21.

Magyarosi Á. (2015): A kabai népkonyha intézménye a világgazdasági válság időszakában (1933-1935). Új nézöpont, 3-4, 51-76.

Molnár Gy., Bakó T., Cseres-Gergely Zs., Kálmán J., Szabó T. (2014): A munkaerőpiac peremén lévók és a költségvetés. A Költségvetési Tanács (KT) és az MTA KRTK közötti szerződés keretében a KT megrendelésére készült tanulmány. http://www.parlament.hu/documents/126660/133966/ MTA+KRTK+KTI+A+munkaer\%C5\%91piac+perem\%C3\%A9n+1\%C3\%A9v\%C5\%91k+\%C3\%A9s+a+k\%C3 \%B6lts\%C3\%A9gvet\%C3\%A9s+jav\%C3\%ADtott.pdf/ba01c982-873e-416c-8b7f-c6684fe55db8 (Letöltés: 2016. július 24.)

Nathan, R. P. (2000): Social science in government: The role of policy researchers. The Rockefeller Institute Press, Albany

Pénzes J. (2014): A területfejlesztés kedvezményezett térségei és települései Magyarországon. Elektronikus oktatási segédanyag földrajz BSc, geográfus és földrajz tanárszakos MSc hallgatók számára. Debreceni Egyetem TTK, Debrecen

Rácz K. (2013): Szegénységkezelés aktív eszközökkel? Egy produktív szociálpolitikai program két évtizedes múködésének tapasztalatai. In: Kovács K., Váradi M. M. (szerk.): Hátrányban, vidéken. Argumentum Kiadó, Budapest, 135-155.

Scharle Á. (2011): A közcélú foglalkoztatás kibövülésének célzottsága, igénybevétele és hatása a tartós munkanélküliségre. Budapest Intézet, Hétfa Elemző Központ, Budapest

Subbarao, K., Ninno, C., Andrews, C., Rodríguez-Alas, C. (2013): Public works as a safety net: Design, evidence, and implementation. World Bank, Washington

Telangana (2015): Government of Telangana Scheduled Castes Sub-plan (SCSP) 2015-16. Volume VII/2. http://finance.telangana.gov.in/uploads/budget-2015-16-books/Volume-VII-2.pdf (Letöltés: 2016. július 20.)

UNDP (2015): MGNREGA Sameeksha II United Nations Development Programme. An anthology of research studies (2012-2014). New Delhi

Váradi M. M. (2010): A közfoglalkoztatás útjai és útvesztői egy aprófalvas kistérségben, Esély, 1., 79-99.

Váradi M. M. (2015): Szegénység, projektek, közpolitikák. Tér és Társadalom, 1., 69-96. http://doi.org/bm2h

World Bank (2007): Implementation completion and results report (Loan 073578) on a loan in the amount of US\$ 600 million to the Argentine Republic for the Jefes The Hogar Program. Report No. ICR355. Human Development Sector Management Unit, Argentina, Chile, Uruguay and Paraguay Country Management Unit, Latin America and Caribbean Regional Office 